JOLANTA ZAWORA

Uniwersytet Rzeszowski, Polska - University of Rzeszów, Poland

\title{
Wykorzystanie partnerstwa publiczno-prywatnego w realizacji inwestycji samorządowych
}

\section{The Use of Public-Private Partnership in Local Government Investments}

Streszczenie: Włączenie partnerów prywatnych do realizacji zadań publicznych przyczynia się przede wszystkim do zwiększenia efektywności gospodarowania w sektorze publicznym oraz przyspieszenia rozwoju jednostek terytorialnych. Partnerstwo publiczno-prywatne (PPP) jest narzędziem wspomagającym rozwój infrastrukturalny, przy jednoczesnym ograniczaniu wielkości wydatków publicznych. Od początku 2009 r., w którym zawarto pierwsze umowy w formule PPP, głównymi inicjatorami projektów pozostają jednostki samorządu terytorialnego. Celem artykułu jest ocena wykorzystania partnerstwa publiczno-prywatnego w Polsce w latach 2009-2019. W artykule zwrócono również uwagę na bariery, które ograniczają rynek PPP w Polsce. Inicjatorem PPP w Polsce są przede wszystkim samorządy szczebla lokalnego, które realizowały najwięcej projektów w dziedzinie infrastruktury transportowej. Najbardziej aktywne były podmioty publiczne położone w regionach najlepiej rozwiniętych gospodarczo. Bariery, które ograniczają rynek PPP, występują najczęściej w obszarze: instytucjonalnym, finansowym, prawnym, postawy oraz wiedzy i umiejętności. W przezwyciężaniu barier niezbędne jest zwiększanie wiedzy w zakresie projektów PPP w celu upowszechnienia współpracy publiczno-prywatnej jako nowoczesnego sposobu realizacji zadań publicznych.

\begin{abstract}
The participation of private partners in the implementation of public tasks contributes above all to increasing the effectiveness of management in the public sector and accelerating the development of territorial units. Public-private partnership (PPP) is a tool that supports infrastructure development while reducing public expenditure. First PPP deals were made in 2009. Since then local government units remained the main initiatiors of the projects. The article aims to assess the use of public-private partnership in Poland in the years 2009-2019. The study also takes into the account the obstacles which impede the development of PPP in Poland. Local governments have implemented the largest number of projects in the field of transport infrastructure in Poland. The most active were public entities located in the regions with the best economic development. The obstacles that limit the PPP initiative are mostly financial, legal, attitudinal. Lack of knowledge and skills also obstructs the development of PPP. Overcoming these barriers requires increasing knowledge of PPP projects in order to promote public-private cooperation as a modern way of implementing public tasks.
\end{abstract}


Słowa kluczowe: inwestycje samorządowe; partnerstwo publiczno-prywatne

Keywords: local development; public-private partnership

Otrzymano: 29 października 2019

Received: 29 October 2019

Zaakceptowano: 18 maja 2020

Accepted: 18 May 2020

\section{Sugerowana cytacja/Suggested citation:}

Zawora, J. (2020). Wykorzystanie partnerstwa publiczno-prywatnego w realizacji inwestycji samorządowych. Przedsiębiorczość - Edukacja [Entrepreneurship - Education], 16(1), 369-380. doi: $10.24917 / 20833296.161 .29$

\section{Wstęp}

Partnerstwo publiczno-prywatne (PPP) jest narzędziem wspomagającym rozwój infrastrukturalny, przy jednoczesnym ograniczaniu wielkości wydatków publicznych. Możliwość realizacji zadań publicznych we współpracy z sektorem prywatnym jest przedmiotem zainteresowania zarówno administracji publicznej, jak i sektora prywatnego. Sektor prywatny poszukuje nowych możliwości rozwoju przez uzyskanie długoterminowego źródła dochodów za zakontraktowane zadania, umiejętności i kwalifikacje. Natomiast strona publiczna upatruje w koncepcji partnerstwa publiczno-prywatnego szansy na pozyskanie kapitału pomocnego w realizacji zadań inwestycyjnych. Ogromne potrzeby w zakresie usług, obiektów i infrastruktury publicznej z jednej strony, a także ograniczenia budżetowe, organizacyjne i kadrowe podmiotów publicznych oraz rosnące zadłużenie z drugiej strony sprawiają, że PPP może stanowić korzystną alternatywę dla tradycyjnego finansowania inwestycji publicznych ze środków budżetowych (Szafran, 2013: 190).

Jednostki samorządu terytorialnego (JST) dzięki prowadzeniu działalności inwestycyjnej powinny zapewniać długotrwały rozwój danego obszaru. Działalność inwestycyjna samorządów powinna gwarantować rozwój jednostki przez aktywizację gospodarczą regionu, a przede wszystkim - prowadzić do poprawy bytu społeczności lokalnej i zaspokajania jej potrzeb (Kołodziej-Hajdo, 2018: 68; Łukomska-Szarek, 2015: 495). Realizacja zadań inwestycyjnych jest uwarunkowana poziomem środków finansowych postawionych do dyspozycji poszczególnych jednostek. W sytuacji, gdy wydatki bieżące pochłaniają przeważającą część środków budżetowych, działalność inwestycyjna zostaje często ograniczona do niezbędnego minimum. Należy wtedy poszukiwać nowych modeli finansowania zadań. Kapitał prywatny wykorzystany do finansowania zadań publicznych może wyraźnie wpłynąć na wielkość realizowanych inwestycji samorządowych (Hajdys, 2014: 49).

Partnerstwo publiczno-prywatne uznaje się również za jedną z koncepcji, które w największym stopniu umożliwiają poprawę efektywności zarządzania realizacją zadań publicznych (Rutkowski, 2010: 39). Istota PPP polega na umownym podziale zadań i ryzyka, aby umiejętności i zasoby każdego z sektorów były optymalnie wykorzystywane przy dostarczaniu usług lub obiektów dla użytku publicznego. Podstawową przewagą PPP nad tradycyjnymi sposobami finansowania jest zatem podział ryzyka, a także zwiększenie efektywności, wynikającej przede wszystkim z udziału sektora prywatnego (Wolniakowska, Ławińska, 2017: 602). Do korzyści, które daje PPP jako formuła realizacji przedsięwzięć inwestycyjnych przez samorządy, poza częściowym odciążeniem sektora publicznego 
od kosztów inwestycyjnych, należy także sprawne zarządzanie inwestycją i dostępnymi zasobami, co przyczynia się do skrócenia czasu rozwoju inwestycji (Moszoro, 2010: 63).

Od początku 2009 r., w którym zawarto pierwsze umowy w formule PPP, głównymi inicjatorami projektów pozostają jednostki samorządu terytorialnego. Celem niniejszego artykułu jest ocena wykorzystania partnerstwa publiczno-prywatnego przez JST w realizacji inwestycji samorządowych. Analizie poddano rozwój partnerstwa publiczno-prywatnego w Polsce na przestrzeni lat 2009-2019. W opracowaniu zwrócono również uwagę na bariery, które ograniczają rynek PPP w Polsce. Ocenę przeprowadzono, wykorzystując dane wtórne, publikowane przede wszystkim przez Ministerstwo Inwestycji i Rozwoju (obecnie Ministerstwo Funduszy i Polityki Regionalnej).

\section{Partnerstwo publiczno-prywatne - istota oraz przesłanki rozwoju}

W bardzo szerokim ujęciu partnerstwo publiczno-prywatne to długoterminowa współpraca sektora publicznego z sektorem prywatnym przy realizacji usług dla społeczeństwa (Partnerstwo publiczno-prywatne..., 2009: 5). W polskim porządku prawnym termin partnerstwo publiczno-prywatne - rozumiany jako oparta na ustawie współpraca podmiotu publicznego z partnerem prywatnym, służąca realizacji zadania publicznego - pojawił się w roku 2005, wraz z wejściem w życie pierwszej ustawy o partnerstwie publiczno-prywatnym (Ustawa z dnia 28 lipca 2005 roku o partnerstwie publiczno-prywatnym, Dz.U. nr 169, poz. 1420, z późn. zm). Ustawa ta, wychodząc naprzeciw ogromnemu zapotrzebowaniu na inwestycje infrastrukturalne, miała uporządkować kwestie współpracy sektora publicznego i prywatnego. Ustawa w praktyce okazała się „martwa”, pod jej regulacjami nie uruchomiono żadnego projektu PPP.

Do rozwoju współpracy podmiotów publicznych i prywatnych przyczyniło się wejście w życie w 2009 r. obecnie obowiązującej Ustawy z dnia 19 grudnia 2008 roku o partnerstwie publiczno-prywatnym (Dz.U. 2019, poz. 1445). Ustawodawca w art. 1 określił w niej, że przedmiotem partnerstwa publiczno-prywatnego jest wspólne realizowanie przez podmiot publiczny oraz podmiot prywatny (przedsiębiorcę lub przedsiębiorcę zagranicznego) przedsięwzięć opartych na podziale zadań i ryzyka między te podmioty. Sposób podziału zadań nie został narzucony odgórnie, pozwalając stronom przydzielić zadania adekwatnie do podmiotu i posiadanych przez niego kompetencji. Wraz z podziałem zadań następuje podział ryzyka, które towarzyszy realizacji przedsięwzięcia. Należy przy tym zauważyć, że umowy partnerstwa powinny wymuszać podział ryzyka pomiędzy obie strony w taki sposób, aby zarządzała nimi ta strona, która jest w stanie wykonać to efektywniej.

O istocie partnerstwa publiczno-prywatnego decydują zatem następujące cechy:

- długoterminowy charakter współpracy,

- montaż finansowy oparty na kapitale prywatnym połączonym z kapitałem innych uczestników procesu (w tym również instytucji finansowych),

- osiąganie korzyści przez obie strony umowy - podmioty publiczne dostarczają usług, które leżą w ich kompetencji, a podmioty prywatne kierują się osiągnięciem założonych stóp zwrotu,

- taki podział zadań i ryzyka między dwóch partnerów, aby umiejętności i zasoby każdego z sektorów były optymalnie wykorzystywane przy dostarczaniu usług lub obiektów dla użytku publicznego (Lissowski, 2012: 10; Jachowicz, 2015: 45). 
Przyczyn wzrastającej tendencji do przekazywania zadań o charakterze publicznym podmiotom prywatnym doszukiwać się można w kilku źródłach, w tym m.in. w:

- oczekiwaniach, że sektor prywatny osiągnie w danej dziedzinie lepsze wyniki,

- dążeniu do pozyskania odpowiednich zasobów technicznych oraz usprawnienia procesu zarządzania,

- konieczności pozyskania środków finansowych umożliwiających zrealizowanie planowanych inwestycji (Delmon, 2011: 13).

Wskazuje się przede wszystkim na większą od administracji publicznej ekonomiczną i społeczną efektywność usług świadczonych przez podmioty prywatne. Podmioty te cechuje także większa skuteczność w wykorzystywaniu posiadanych środków. Przedsiębiorca prywatny wnosi do procesu świadczenia usług publicznych również kreatywność i doświadczenie zdobyte na wolnym rynku. Strona publiczna dysponuje władztwem, zaś strona prywatna wnosi wiedzę o efektywnym zarządzaniu, nowoczesne technologie, kapitał oraz skuteczność prowadzenia działalności. Prowadzi to do usprawnienia i podniesienia poziomu świadczonych usług publicznych z jednej strony, a do obniżenia ich kosztów ze strony drugiej. Istotnymi przesłankami podejmowania przez sektor publiczny inicjatyw PPP są ponadto:

- duży deficyt środków publicznych oraz rosnące zadłużenie podmiotów publicznych,

- rosnące oczekiwania społeczne w zakresie jakości i dostępności infrastruktury oraz usług o charakterze publicznym,

- ograniczone zdolności jednostek samorządu terytorialnego do finansowania działalności inwestycyjnej (Hausner, 2013).

Realizacja zadań inwestycyjnych jest uwarunkowana sytuacją finansową poszczególnych jednostek. Szybka dynamika wzrostu oczekiwań społecznych zestawiona z pogarszającymi się możliwościami finansowymi budżetów publicznych przyczynia się do narastania sytuacji kryzysowych i poszukiwania nowych modeli finansowania zadań.

Inwestycje samorządowe - charakter i znaczenie

Inwestycje prowadzone przez jednostki samorządu terytorialnego służą interesowi publicznemu, powinny zatem zaspakajać potrzeby społeczno-gospodarcze danej społeczności (Filipiak, Dylewski, 2015: 868-869). Za inwestycje komunalne należy uznać celowe wydatkowanie środków finansowych przez daną JST, nakierowane na powiększenie materialnych i niematerialnych korzyści wspólnoty samorządowej (Czempas, 2004: 85). Sfera inwestycji samorządowych sprowadza się przede wszystkim do lokowania środków finansowych w infrastrukturę gospodarczą i społeczną, np. budowę dróg, systemów transportu wodnego, systemów energetycznych, wodociągów, szkół, szpitali, obiektów sportowych i rekreacyjnych (Pilecki, 2019: 66). Inwestycje infrastrukturalne realizowane przez jednostki samorządu terytorialnego są niezbędne dla rozwoju społeczno-gospodarczego w skali regionalnej i lokalnej. Infrastruktura - rozumiana jako całokształt zasobów materialnych oraz instytucjonalnych - jest bazą dla zaspokojenia podstawowych potrzeb ludności, prowadzenia działalności gospodarczej, a także zapewnienia dostępności terytorialnej. Poziom zagospodarowania infrastrukturalnego ma zatem istotne znaczenie dla inicjowania i przyspieszania wzrostu aktywności gospodarczej na danym terenie (Kozłowski, 2012). 
Oznaką rozwoju, czyli podążaniem za potrzebami społeczności lokalnej i kształtowaniem nowych potrzeb, jest realizacja przez JST przedsięwzięć z zakresu infrastruktury technicznej i społecznej. Wdrażane inwestycje przekładają się na wzrost konkurencyjności jednostki samorządowej, a także wpływają na poziom życia jej mieszkańców dzięki poprawie ilości i jakości realizowanych usług komunalnych i społecznych. Wspieranie rozwoju społeczno-gospodarczego jest realizowane przede wszystkim przez: powstawanie nowych przedsiębiorstw i miejsc pracy oraz utrzymanie i rozwój już funkcjonujących przedsiębiorstw, a także dodatnie saldo migracji ludności i kształtowanie pożądanej struktury demograficznej (Zawora J., Zawora P., 2019: 8). Infrastrukturalne przedsięwzięcia inwestycyjne wpływają w pozytywny sposób na działalność już istniejących podmiotów, powodując wzrost zatrudnienia w lokalnych firmach zaangażowanych w ich realizację oraz w jednostkach kooperujących z nimi, a także w instytucjach otoczenia biznesu. Dając pracę miejscowym podmiotom, tworzą koniunkturę na rynku (Zimny, 2008). Powstaje więc spirala inwestycyjna: przemyślane inwestycje infrastrukturalne pociągają za sobą kolejne, co jest najskuteczniejszą metodą zapobiegania bezrobociu. Inwestycje samorządowe sprzyjają pozyskiwaniu przedsiębiorców i powstawaniu nowych inwestycji, co przekłada się również na zwiększanie dochodów budżetowych, zwłaszcza dochodów własnych, decydujących o możliwościach rozwojowych samorządów.

Wśród cech charakterystycznych działalności inwestycyjnej JST, poza użytecznością społeczno-gospodarczą, należy wymienić m.in.: wysoką kapitałochłonność, problem osiągnięcia efektywności i zwrotu z poniesionych nakładów, długi okres jej użytkowania przez społeczeństwo, ryzyko inwestycyjne i finansowe (Filipiak, Dylewski, 2015: 869; Zawora J., Zawora P., 2019: 9).

Należy przy tym pamiętać, że działalność inwestycyjna samorządów polega nie tylko na tworzeniu nowych inwestycji, lecz także na ich odtwarzaniu. Istotną kwestią jest wobec tego wydolność infrastrukturalna, związana z ciągłym ulepszaniem i modernizacją infrastruktury oraz jednoczesnym nadążaniem za popytem i potrzebami zgłaszanymi przez społeczność lokalną i podmioty gospodarujące na danym terenie (Zawora, Kogut-Jaworska, Jachowicz, 2017: 28). Należy także dodać, że inwestycje samorządowe mają charakter ciągły, więc wydatki z nimi związane regularnie obciążają budżety gmin, powiatów lub województw. Odtwarzanie zużytego majątku i dalszy rozwój jednostek samorządu terytorialnego wymagają stałych nakładów finansowych.

Wobec ograniczeń budżetowych i wysokiego poziomu zadłużenia samorządów oraz przy stale rosnących potrzebach społeczeństw rośnie rola partnerstwa publiczno-prywatnego w realizacji inwestycji komunalnych, dzięki zaangażowaniu w procesy inwestycyjne kapitału prywatnego.

\section{Wykorzystanie partnerstwa publiczno-prywatnego w Polsce w latach 2009-2019}

Pierwsze umowy w formule PPP zawarto w Polsce w 2009 r. Według danych raportu opublikowanego przez Ministerstwo Inwestycji i Rozwoju, od początku 2009 r. do 30 czerwca 2019 r. wszczęto łącznie 557 postępowań PPP, mających na celu wybór partnera prywatnego i zawarcie umowy (Raport rynku PPP, 2019). Spośród wszystkich zawartych umów zdecydowana większość (135) weszła w fazę realizacji. Osiemnaście umów nie jest realizowanych, w większości przypadków z powodu wcześniejszego rozwiązania. 
Niewielka liczba realizowanych projektów wskazuje na podstawową słabość polskiego rynku PPP, którą jest mała skuteczność działań podmiotów publicznych (niska przekładalność liczby ogłoszeń o wyborze partnera prywatnego na zawierane i realizowane umowy). W latach 2009-2019 realizowane umowy stanowiły średnio ok. 24\% pierwotnej liczby ogłoszeń. Warto jednak podkreślić, że od 2017 r. skuteczność postępowań PPP mierzona stosunkiem podpisanych umów do wszczętych postępowań kształtuje się na poziomie 32\% (Raport rynku PPP, 2019).

Tabela 1. Liczba wszczętych postępowań i zawartych umów PPP w latach 2009-2019*

\begin{tabular}{|c|c|c|c|c|}
\hline Lata & $\begin{array}{c}\text { Wszczęte } \\
\text { postępowania }\end{array}$ & $\begin{array}{c}\text { Zawarte } \\
\text { umowy }\end{array}$ & $\begin{array}{c}\text { Realizowane } \\
\text { umowy }\end{array}$ & $\begin{array}{c}\text { Nierealizowane } \\
\text { umowy }\end{array}$ \\
\hline 2009 & 38 & 2 & 2 & 0 \\
\hline 2010 & 60 & 12 & 8 & 4 \\
\hline 2011 & 43 & 13 & 11 & 2 \\
\hline 2012 & 80 & 20 & 15 & 5 \\
\hline 2013 & 70 & 23 & 20 & 3 \\
\hline 2014 & 52 & 18 & 16 & 2 \\
\hline 2015 & 61 & 25 & 23 & 2 \\
\hline 2016 & 60 & 10 & 10 & 0 \\
\hline 2017 & 36 & 11 & 11 & 0 \\
\hline 2018 & 47 & 16 & 16 & 0 \\
\hline 2019 & 10 & 3 & 3 & 18 \\
\hline Łącznie & 557 & 153 & 135 & 0 \\
\hline
\end{tabular}

* I i II kwartał 2019 r.

Źródło: opracowanie własne na podstawie: Raport rynku PPP (2019)

Podmioty publiczne próbowały stosować formułę PPP w szerokim zakresie, praktycznie we wszystkich sferach usług użyteczności publicznej. W okresie od 2009 r. do końca czerwca 2019 r. wszczęto postępowania PPP w 15 sektorach, przy czym trzy czołowe sektory (sport i turystyka - 144, infrastruktura transportowa - 84 i efektywność energetyczna - 52) stanowiły około połowy wszystkich postępowań. Najwięcej umów PPP realizowanych było w sektorach: infrastruktura transportowa (21), sport i turystyka (20), efektywność energetyczna (20). Pod względem wartości dominowały dwa sektory: $28 \%$ stanowiły projekty z sektora telekomunikacji, a $24 \%$ - projekty dotyczące gospodarki odpadami. Ogółem do końca czerwca 2019 r. w ramach PPP zawarto umowy PPP o łącznej wartości ponad 6 mld zł (tabela 2).

Struktura przedmiotowa polskich projektów PPP różni się od struktury projektów realizowanych w Europie i na świecie (Jachowicz, 2015: 161). Większość projektów w ramach PPP dotyczy w tych krajach edukacji, natomiast najwyższą wartość stanowi infrastruktura drogowa. Podstawowej przyczyny tego stanu rzeczy szukać należy w strukturze aktywności podmiotów publicznych korzystających z instrumentu PPP i przypisanych im kompetencji. W Polsce inicjatorem PPP są przede wszystkim władze gminne, w Europie podmioty publiczne szczebla ponadlokalnego (Hausner, 2013). 
Tabela 2. Liczba i wartość umów PPP w podziale na sektory w latach 2009-2019*

\begin{tabular}{|l|c|c|c|}
\hline \multicolumn{1}{|c|}{ Sektory } & $\begin{array}{c}\text { Liczba } \\
\text { wszczętych } \\
\text { postępowań }\end{array}$ & $\begin{array}{c}\text { Wartość } \\
\text { realizowanych } \\
\text { projektów } \\
\text { w mln zl }\end{array}$ & $\begin{array}{c}\text { Liczba } \\
\text { realizowanych } \\
\text { projektów }\end{array}$ \\
\hline Telekomunikacja & 21 & 1656 & 9 \\
\hline Gospodarka odpadami & 20 & 1415 & 7 \\
\hline Rewitalizacja & 13 & 630 & 2 \\
\hline Infrastruktura transportowa & 84 & 617 & 21 \\
\hline Sport i turystyka & 144 & 424 & 20 \\
\hline Efektywnóś energetyczna & 52 & 333 & 20 \\
\hline Ochrona zdrowia & 31 & 207 & 4 \\
\hline Gospodarka wodno-kanalizacyjna & 33 & 172 & 15 \\
\hline Budynki publiczne & 13 & 161 & 6 \\
\hline Kultura & 15 & 132 & 9 \\
\hline Usługi transportowe & 32 & 105 & 5 \\
\hline Edukacja & 22 & 80 & 14 \\
\hline Pozostałe & 77 & 93 & 135 \\
\hline Eącznie & 557 & 6024 & \\
\hline
\end{tabular}

* I i II kwartał 2019 r.

Źródło: opracowanie własne na podstawie: Raport rynku PPP (2019)

Analiza struktury podmiotów publicznych zainteresowanych realizacją przedsięwzięć PPP wskazuje na to, że w Polsce inicjatorem PPP są przede wszystkim jednostki samorządu terytorialnego (w tym przede wszystkim szczebla lokalnego). W latach 2009-2019 samorządy zawarły (bezpośrednio lub przez jednostki z nimi związane) 120 umów (89\%). Najwięcej kontraktów, które weszły w stadium realizacji, podpisały gminy, w tym: miejskie (40 umów), wiejskie (28 umów) i miejsko-wiejskie (21 umów). Tylko 15 umów PPP zostało zawartych przez podmioty niepowiązane z samorządem.

Liczba umów PPP w podziale na rodzaj podmiotu publicznego przedstawia się następująco:

- gminy - 89,

- urzędy marszałkowskie - 10,

- jednostki budżetowe - 9,

- administracja rządowa - 7,

- spółki komunalne - 6,

- starostwa powiatowe - 4,

- jednostki służby zdrowia - 3,

- uczelnia - 2,

- inne- 5 .

Specyfiką polskiego rynku PPP, odróżniającą go od rynku innych krajów, jest dominacja małych wartościowo projektów. Jest to ściśle związane z niższą aktywnością w Polsce podmiotów publicznych szczebla ponadlokalnego. Analiza struktury wartości 
projektów pokazuje, że na rynku polskich projektów PPP dominują umowy, których wartość nie przekracza $40 \mathrm{mln}$ zł - łączna ich liczba stanowi 80\% wszystkich umów PPP. Liczba umów w podziale na wartość projektu:

- mikro (<5 mln zł) - 59,

- małe (5-40 mln zł) - 48,

- duże (40-100 mln zł) - 16,

- bardzo duże (100-500 mln zł) - 10,

- największe (> 500 mln zł) - 2 .

Umowy PPP realizowane w latach 2009-2019 mające najwyższą wartość to:

1. System gospodarki odpadami dla miasta Poznania (783 mln zł),

2. System gospodarki odpadami dla metropolii trójmiejskiej (570 mln zł),

3. Zagospodarowanie północnego cypla Wyspy Spichrzów w Gdańsku (491 mln zł),

4. Internet dla Mazowsza (458 mln),

5. Budowa Wielkopolskiej Sieci Szerokopasmowej (410 mln).

Wartość tych pięciu umów to prawie 50\% wartości wszystkich dotychczas zawartych umów PPP.

Największa koncentracja realizowanych w formule PPP przedsięwzięć występowała w regionach najlepiej rozwiniętych gospodarczo. Pod względem zawartych umów w analizowanym okresie dominują województwa: mazowieckie (26 realizowanych umów), śląskie (20), pomorskie (16) i dolnośląskie (15). Najmniej aktywne były podmioty publiczne znajdujące się na terenie województwa lubelskiego, gdzie doszło do realizacji tylko jednego projektu. Po 2 projekty w analizowanym czasie zrealizowano w województwach: podkarpackim, podlaskim i lubuskim. Niską aktywnością charakteryzowały się także podmioty w województwie świętokrzyskim (3 zawarte umowy). Można zatem zauważyć, że na terenie województw słabiej rozwiniętych gospodarczo inicjatywy w zakresie PPP występowały najrzadziej, mimo że są to jednocześnie obszary o wysokich potrzebach inwestycyjnych. Należy jednak pamiętać, że przygotowanie przedsięwzięcia w formule PPP łączy się z wysokimi kosztami, natomiast jednostki samorządowe, które są głównymi inicjatorami PPP, charakteryzują się $\mathrm{w}$ tych regionach najniższym potencjałem dochodowym.

\section{Bariery rozwoju PPP w Polsce}

Polski rynek partnerstwa publiczno-prywatnego jest ciągle w fazie rozwoju. Istotną kwestią umożliwiającą zwiększenie efektywności wdrażanych działań jest trafna identyfikacja barier utrudniających realizację projektów PPP (Mapa barier..., 2019). Bariery, które ograniczają rynek PPP, występują najczęściej w następujących obszarach:

- instytucjonalnym - liczne formalności i długi okres przygotowań do finalizacji umowy, niepowodzenia takich projektów w przeszłości (znaczna liczba unieważnianych postępowań), skomplikowane procedury dotyczące przygotowania projektu, przeprowadzenia analiz oraz procedury wyboru partnera prywatnego, słabe wykorzystywanie pozytywnych doświadczeń i wzorców dotyczących stosowania PPP, brak wzorcowych dokumentów, standardów, opisanych dobrych praktyk, które mogłyby być wykorzystywane przy realizacji projektów, niedostateczna edukacja w zakresie przygotowywania projektów PPP oraz słaba promocja współpracy sektora publicznego i prywatnego w ramach PPP; 
- finansowym - wysoka kapitałochłonność przedsięwzięć i trudności w pozyskiwaniu kapitału, wysoki koszt kapitału prywatnego, długi okres realizacji i eksploatacji projektu utrudniający ocenę rentowności projektu, kosztowność przygotowania projektu, wysokie koszty analiz finansowych, technicznych i prawnych dostarczanych przez specjalistyczne firmy zewnętrzne;

- prawnym - skomplikowana procedura przygotowania umowy partnerstwa pod względem prawnym, przede wszystkim trudności w dokonaniu oceny umowy o PPP pod kątem rozkładu ryzyka projektowego, niejednoznaczność przepisów prawa;

- postawy (po stronie instytucji publicznych, jak i przedsiębiorców) - niechęć decydentów podmiotów publicznych, a także przedsiębiorców do współpracy oraz nieufne nastawienie społeczeństwa i organów kontrolujących do współpracy między przedstawicielami władzy a biznesem, obawy przedstawicieli podmiotów publicznych przed negatywnymi konsekwencjami wynikającymi z podejmowania błędnych decyzji;

- wiedzy i umiejętności - brak odpowiedniej kadry (przede wszystkim po stronie podmiotów publicznych), niedostateczny poziom wiedzy i doświadczenia osób przygotowujących projekty PPP, w szczególności w zakresie przygotowania technicznego projektu, przeprowadzenia analiz, podziału zadań i ryzyk pomiędzy stronami oraz procedury wyboru partnera prywatnego. Potwierdza to m.in. niska relacja zawartych umów PPP do liczby ogłoszonych postępowań, która wskazuje na małą skuteczność działań podmiotów publicznych (Jachowicz, 2015; Paczoski, 2014; Zawora J., Zawora P., 2014).

Wśród cech utrudniających realizację przedsięwzięć PPP należy również wymienić ich długoterminowość - długi okres przygotowania projektu, jego realizacji i eksploatacji. Powoduje to występowanie trudności w relacjach między stroną publiczną a stroną prywatną w okresie zawartej umowy, tj. często kilkunastu lub kilkudziesięciu lat. Przeszkodą w nawiązaniu współpracy jest kadencyjność władz samorządowych. PPP, ponieważ współpraca ta jako proces długoterminowy wymaga planów wykraczających poza jedną kadencję wyborczą.

Szczególnie istotne jest przezwyciężanie barier mentalnych, z których wynikają obawy i ostrożność podmiotów publicznych oraz prywatnych w podejmowaniu inicjatyw w zakresie PPP. Wiążą się one z niską świadomością, niedostatecznym poziomem wiedzy i doświadczenia w zakresie projektów PPP. Przeszkodą do szerokiego korzystania z partnerstwa publiczno-prywatnego jest głównie niedostateczne zrozumienie zasad działania tego instrumentu. Przede wszystkim niezbędna jest popularyzacja wiedzy na temat prawnych i finansowych aspektów związanych z PPP (Partnerstwo..., 2019). Konieczne jest także upowszechnianie dobrych praktyk dotyczących wdrażania projektów PPP.

\section{Podsumowanie}

Z wykorzystaniem formuły PPP wiąże się wiele korzyści. Włączenie partnerów prywatnych do realizacji zadań publicznych przyczynia się do zwiększenia efektywności gospodarowania w sektorze publicznym oraz przyspieszenia rozwoju jednostek terytorialnych. Ponadto strona publiczna upatruje w tej koncepcji szansy na pozyskanie kapitału pomocnego w realizacji zadań inwestycyjnych.

Analizując polski rynek partnerstwa publiczno-prywatnego, zauważamy jego stopniowy rozwój. PPP w Polsce rozwija się głównie dzięki zaangażowaniu samorządów, które 
podpisały prawie 90\% wszystkich umów zawartych w formule PPP. Specyfiką polskiego rynku PPP, odróżniającą go od rynku innych krajów, jest ponadto dominacja małych wartościowo projektów, co wynika z wysokiej aktywności w tej dziedzinie samorządów szczebla lokalnego. Najbardziej aktywne były przy tym jednostki samorządowe położone w regionach najlepiej rozwiniętych gospodarczo, charakteryzujące się relatywnie wysokim potencjałem dochodowym.

Skuteczne wdrażanie formuły PPP utrudniają cechy tej współpracy. Jest to bowiem długoterminowa i skomplikowana pod względem prawnym oraz kosztowna formuła realizacji zadań inwestycyjnych. Ponadto, rozwój PPP skutecznie blokuje obawa partnerów publicznych i prywatnych przed wspólną realizacją przedsięwzięć. W przezwyciężaniu barier ograniczających rynek PPP niezbędne jest zwiększanie wiedzy w zakresie projektów PPP w celu upowszechnienia współpracy publiczno-prywatnej jako nowoczesnego sposobu realizacji zadań publicznych.

W sytuacji braku niezbędnego kapitału finansującego inwestycje publiczne, to PPP może być jedną z ważniejszych formuł zapewnienia rozwoju kraju. Pomimo widocznego od lat zainteresowania PPP ze strony jednostek samorządu terytorialnego dla inwestycji rządowych w Polsce, PPP nadal jest narzędziem rzadko stosowanym (Rozwój PPP $w$ Polsce..., 2019). W celu bardziej dynamicznego rozwoju współpracy opartej na partnerstwie publiczno-prywatnym potrzebna jest intensyfikacji działań w zakresie realizacji inwestycji rządowych w tej formule.

Literatura

References

Czempas, J. (2004). Inwestycje gminne - zakres i pomiar. W: Polska samorządność w integrującej się Europie. Szczecin: Fundacja na Rzecz Uniwersytetu Szczecińskiego.

Delmon, J. (2011). Public-Private Partnership Projects in Infrastructure. An Essential Guide for Policy Makers. The World Bank.

Filipiak, B., Dylewski, M. (2015). Działalność inwestycyjna jednostek samorządu terytorialnego w latach 2008-2013. Zeszyty Naukowe Uniwersytetu Szczecińskiego, 854. Finanse, Rynki Finansowe, Ubezpieczenia, 73, 867-877.

Hajdys, D. (2014). Partnerstwo publiczno-prywatne a polityka inwestycyjna samorządów. Finanse Komunalne, 3, 49-56.

Hausner, J. (red.). (2013; 2019, 20 października). Raport o partnerstwie publiczno-prywatnym w Polsce. Pozyskano z: https://docplayer.pl/1608173-Raport-o-partnerstwie-publiczno-prywatnym-w-polsce.html

Jachowicz, A. (2015). Partnerstwo publiczno-prywatne narzędziem efektywnej realizacji zadań publicznych. Warszawa: Difin.

Kołodziej-Hajdo, M. (2018). Analiza i ocena działalności inwestycyjnej polskich gmin przez pryzmat ich zadłużenia w aspekcie wykorzystania środków unijnych. Wspólczesna Gospodarka, 9(1), 67-78.

Kozłowski, W. (2012). Zarzadzanie gminnymi inwestycjami infrastrukturalnymi. Warszawa: Difin.

Lissowski, O. (2012). Partnerstwo publiczno-prywatne i świadczenie uslug publicznych. Poznań: Polskie Wydawnictwo Prawnicze.

Łukomska-Szarek, J. (2015). Ocena działalności inwestycyjnej gmin w województwie śląskim. W: D. Zarzecki (red.), Mierzenie i ocena wyników przedsiębiorstw. Szczecin: Wydawnictwo Naukowe Uniwersytetu Szczecińskiego, 495-508.

Mapa barier rozwoju projektów PPP w Polsce w ocenie partnerów biznesowych. (2019, 28 października). Pozyskano z: http://docplayer.pl/7156847-Www-pwc-com-mapa-barier-rozwoju-projektow-pppw-polsce-w-ocenie-partnerow-biznesowych.html 
Moszoro, M. (2010). Partnerstwo publiczno-prywatne w sferze użyteczności publicznej. Warszawa: Wolters Kluwer Polska.

Paczoski, A. (2014). Charakterystyka funkcjonowania partnerstwa publiczno-prywatnego w Polsce. W: G. Wrzeszcz-Kamińska, I. Ścibiorska-Kowalczyk (red.), Partnerstwo publiczno-prywatne. Wybrane zagadnienia. Dobrzeń Wielki: Uniwersytet Ekonomiczny we Wrocławiu, 51-69.

Partnerstwo publiczno-prywatne. Przemyśl, przygotuj, przeprowadź. (2009). Praca zbiorowa. Warszawa: Wydawnictwo C.H. Beck.

Partnerstwo publiczno-prywatne: zagrożenia i bariery. (2019, 20 października). Pozyskano z: https:// www.rp.pl/artykul/1142824-Partnerstwo-publiczno-prywatne--zagrozenia-i-bariery.html

Pilecki, B. (2019). Infrastruktura społeczna i jej znaczenie w rozwoju regionalnym. Szczecin: Wydawnictwo Naukowe Uniwersytetu Szczecińskiego.

Raport rynku PPP. (2019, 20 października). Pozyskano z https://www.ppp.gov.pl/media/system/slowniki/Raport-z-rynku-PPP-I-i-II-kw-2019.pdf

Rozwój PPP w Polsce wymaga zwiększenia liczby projektów rządowych. (2019, 20 października). Pozyskano z: https://sobieski.org.pl/rozwoj-ppp-w-polsce-wymaga-zwiekszenia-liczby-projektow-rzadowych/

Rutkowski, J. (red.). (2010). Partnerstwo publiczno-prywatne w Polsce i jego funkcjonowanie na przykładzie wybranych projektów. Łódź: Wydawnictwo Uniwersytetu Łódzkiego.

Szafran, J. (2013). Kierunki i zakres stosowania partnerstwa publiczno-prywatnego w Polsce. Annales Universitatis Mariae Curie-Skłodowska. Sectio H, Oeconomia, 47(1), 189-199.

Ustawa z dnia 28 lipca 2005 r. o partnerstwie publiczno-prywatnym. Dz.U. nr 169, poz. 1420, z późn. zm. Ustawa z dnia 19 grudnia 2008 r. o partnerstwie publiczno-prywatnym. Dz.U. 2019, poz. 1445.

Wolniakowska, K., Ławińska, O. (2017). Partnerstwo publiczno-prywatne jako droga rozwoju sektora publicznego oraz przedsiębiorstw w Polsce w latach 2009-2016. Zeszyty Naukowe Politechniki Śląskiej, 114, 601-616.

Zawora, J., Kogut-Jaworska, M., Jachowicz, A. (2017). Działalność inwestycyjna gmin w Polsce. Radom: Instytut Naukowo-Wydawniczy „Spatium”.

Zawora, J., Zawora, P. (2019). Determinanty finansowe realizacji inwestycji przez jednostki samorządu terytorialnego w latach 2013-2018. Finanse Komunalne, 11-12, 7-17.

Zawora, J., Zawora, P. (2014). Partnerstwo publiczno-prywatne jako forma finansowania działalności inwestycyjnej samorządów lokalnych. Nierówności Społeczne a Wzrost Gospodarczy, 40, 324-333.

Zimny, A., (2008). Uwarunkowania efektywności inwestycji gminnych w sferze infrastruktury technicznej. Konin: Państwowa Wyższa Szkoła Zawodowa w Koninie.

Jolanta Zawora, dr, Uniwersytet Rzeszowski, Instytut Ekonomii i Finansów, Katedra Ekonomiki i Zarządzania. Jej zainteresowania badawcze obejmują dziedziny ekonomii i finansów i koncentrują się na finansach samorządu terytorialnego w następujących kwestiach: ocena sytuacji finansowej samorządów oraz identyfikacja czynników determinujących zróżnicowanie regionalne ich potencjału finansowego, analiza niezależności finansowej samorządów i ich zdolności do rozwoju, efektywność wydatków budżetowych samorządu terytorialnego.

Jolanta Zawora, PhD, University of Rzeszów, Institute of Economics and Finance, Department of Economics and Management. Her research interests include the fields of economics and finance, especially local government finances. She focuses on the following issues: assessment of financial situation of local governments and identification of factors that determine financial conditions with regard to regional disparities, analysis of financial independence of local government and its capacity for development, the effectiveness of local government budgetary expenditures.

ORCID: https://orcid.org 0000-0003-4180-258X 


\section{Adres/Address:}

Uniwersytet Rzeszowski

Instytut Ekonomii i Finansów

Katedra Ekonomiki i Zarządzania

ul. M. Ćwiklińskiej 2

35-601 Rzeszów, Polska

e-mail: jolazawora@gmail.com 